This item was submitted to Loughborough's Research Repository by the author.

Items in Figshare are protected by copyright, with all rights reserved, unless otherwise indicated.

\title{
Something alien? The limits of U.S. influence in UK campaigns
}

PLEASE CITE THE PUBLISHED VERSION

http://dx.doi.org/10.1080/15377857.2016.1262222

PUBLISHER

(c) Taylor \& Francis

VERSION

AM (Accepted Manuscript)

PUBLISHER STATEMENT

This work is made available according to the conditions of the Creative Commons Attribution-NonCommercialNoDerivatives 4.0 International (CC BY-NC-ND 4.0) licence. Full details of this licence are available at: https://creativecommons.org/licenses/by-nc-nd/4.0/

\section{LICENCE}

CC BY-NC-ND 4.0

\section{REPOSITORY RECORD}

Wring, Dominic. 2019. "Something Alien? the Limits of U.S. Influence in UK Campaigns". figshare. https://hdl.handle.net/2134/25056. 
"Something Alien to Our British Democracy": (the limits of) American influence on UK election campaigning

\author{
Dominic Wring \\ Department of Social Sciences \\ Loughborough University \\ Ashby Road \\ Loughborough \\ Leicestershire \\ United Kingdom \\ LE11 3TU \\ D.J.Wring@lboro.ac.uk
}

\begin{abstract}
The campaign consulting business in the United States is the largest in the world and has had some success in globally exporting its expertise in terms of both personnel and technique. This paper reflects on the so-called 'Americanization' of British elections and draws attention to some of the significant landmarks in the relationship between strategists in the two countries. The discussion does, however, identify the limitations of this idea as an organizing concept for understanding how election campaigning has developed in the UK.
\end{abstract}

Keywords: British politics, election campaigning, campaign consultants, Americanization, public intellectuals, marketing history. 
The notion of Americanization has received considerable attention in political communication as well as wider social scientific debate. But this idea has gone out of fashion in favour of other perspectives that are less keen on foregrounding this particular factor as a driver of change (Swanson and Mancini, 1996). This is especially the case with elections where there was a long-running belief that certain countries, Britain in particular, were experiencing transformative changes as a consequence of the arrival of United States campaign consultants if not directly in person then in terms of their techniques. But the growth of this debate helped challenge this assumption as various alternative explanations were offered including theories that foreground concepts such as media logic/mediatisation (Altheide and Snow, 1979), modernization (Farrell, 1996), professionalization (Negrine, 2008) and marketization (Savigny and Wring, 2009). Each of these offers a more nuanced account than Americanization and demonstrates growing recognition that indigenous factors and circumstances are still highly important in shaping political communication in any given national context (Blumler et al., 1996).

Mass politics and democracy developed in tandem together with new, more pervasive forms of media and communication at the turn of the Twentieth Century. This was also a period of significant growth in adult literacy as well as the greatest expansion of the electoral franchise amongst the most advanced industrial societies including Britain. The arrival of (near) universal suffrage alerted political elites to the limitations of their traditional interpersonal forms of address and of the increasing need for them to be able to reach a much enlarged, more heterogeneous public. Political communication via different media then became the norm during campaigns that increasing went beyond simply trying to publicize an issue or candidature and became increasingly about more sophisticated methods of engaging and persuading a mass audience. This helped transform elections and define practices in leading democratic states throughout the world, and particularly during the middle of the Century. And it was then that the idea of Americanization became a marked feature of political 
discourse. The following discussion will examine how this informed developments in Britain having first explored how US public intellectuals came to shape and influence understanding in the field.

\section{Campaigning: theoretical perspectives}

Early pioneering studies of election campaigning were often incorporated into wider studies of political systems. The scholars involved came from a range of countries and included Moisei Ostrogorski from Russia, the German Robert Michels and Britain's Graham Wallas. Collectively their and others' work contributed to the promotion of comparative analysis (Ostrogorski, 1902; Wallas, 1908; Michels, 1915). Wallas, a London School of Economics professor, was particularly concerned with theorising the relationship between electors and elected in his groundbreaking study Human Nature in Politics published at the outset of the Twentieth Century. Informed by then important developments in the field of psychology the book suggested classic democratic theory underestimated the potential influence of a more robustly emotive kind of campaign appeal as rival candidates vied to outdo each other for the attention of voters who were not necessarily that engaged with the issues. Wallas therefore suggested image based advertising might be a more persuasive form of political communication than interpersonal or educational based appeals when dealing with a mass electorate.

The relevance of Wallas' work applies to various practical examples, notably involving gimmicky or negative campaigns. Advertising agent Charles Higham, a contemporary public figure who was arguably the first British political strategist of the mass media age, clearly subscribed to the view that politics could and should be promoted as though a conventional commercial product (Higham, 1920). This view was not the received wisdom at the time; however, within a few years, Higham would get his chance to put his ideas into practice through becoming an MP and helping his party manage its campaign efforts. If practitioner experience 
reinforced the importance of Wallas' ideas his work also had an important theoretical legacy in that Human Nature in Politics covers terrain that has been revisited by some of the most influential public intellectuals such as Jurgen Habermas and, more recently, Drew Westen (Habermas, 1962; Westen, 2007). Whereas Habermas bemoaned the diminution of critical-rational debate, Westen suggested this was inevitable and that liberal progressive candidates needed to carefully and skilfully manage their images in order to challenge for office.

Westen's book The Political Brain appeared a century after Human Nature in Politics was first published and despite coming to a similar conclusion it is striking that there was no acknowledgement of the earlier work by the latter. This is perhaps understandable because the British scholar has never gained the same recognition afforded to some of his peers engaged in similar debates. Notable among the latter was Wallas' friend Walter Lippman, an American writer who was at the forefront of the debate about the interplay between mass media and enlarged electorate. It is no coincidence that the 1920s saw the publication of major works dealing with the development of strategic communication including Lippman's classic Public Opinion, a book that explored and promoted the desirability of elites manufacturing consent (Lippman, 1922). Similar sentiments informed contributions from another (Austrian-) American writer, Edward Bernays, populariser of the concept and practice of public relations. Bernays advocated the best means of influencing mass opinion was through the solicitation of favourable coverage from a range of news media outlets that reached the largest possible audiences (Bernays, 1923).

Lippman, Bernays and other US based public intellectuals of the inter-war period were writing about developments that were clearly informed by the rapidly changing nature of the growing 'mass society'. Concomitant with this was a burgeoning marketing industry that rapidly expanded as the American economy helped to transform the country into a global power during the mid-Twentieth Century. After the Second World War the US emerged and had clearly usurped 
the leading position of other major international states, notably Britain. Furthermore the onset of the Cold War provided an obvious context and the ideological as well as business rationale for the American government to want to encourage the promotion of consumerism through marketing activities. This was most graphically illustrated in the notorious 1959 'kitchen debate' confrontation between Soviet leader Khruschev and Vice-President Nixon. Nixon himself had been a beneficiary of the application of marketing to politics in the guise of Rosser Reeves, populariser of the phrase Unique Selling Point, and a key strategist work in the successful campaign that took Ike Eisenhower to the White House.

The nature of Eisenhower's victory and other groundbreaking political communication initiatives during this period encouraged more academics to begin studying campaigns. Prominent among them was Stanley Kelley whose influential 1956 book on the subject features the first known use of the term 'political marketing' (Kelley, 1956). The following year another American scholar, Anthony Downs, published his now classic An Economic Theory of Democracy that likened parties to firms and voters to sovereign consumers operating in a marketplace (Downs, 1957). Downs helped popularise a model of electoral competition based upon a now familiar adage: candidates can best mobilise the support of median voters by aligning themselves more closely towards their principal opponent's position and therefore, by extension, the ideological 'centreground'. This influential perspective is of course indelibly linked to that most decisively two dimensional- Democrat versus Republican- of party systems, a model that is not necessarily representative of others. The following decade saw further important conceptual work fusing political with economic theory in relation to electoral studies. Here the contribution was from the burgeoning field of management studies, itself another example of the increasing influence of the American academy in the post-war era. Thus in their groundbreaking essay on the need for a wider, more socially aware conception of marketing, Kotler and Levy argued this extended to elections because: 'Political contests remind us 
that candidates are marketed as well as soap' (Kotler and Levy, 1969). Such a perspective had, of course, been reinforced by the rapid growth of primarily United States based campaign consultancy during this time.

The centrality of consultants and marketing to politics were dramatically illustrated with the election of Ronald Reagan in 1980, a politician who was widely perceived to have made up for his lack of intellectual agility through a supposed self-promotional ability that led to him being hailed the 'great communicator'. Critically this victory demonstrated that it was possible for socalled 'conviction' politicians to appeal to potential supporters without necessarily alienating core supporters. Guided by an ambitious programme of voter research directed by Richard Wirthlin, Reagan's team used careful strategic positioning to achieve success (Perry, 1984). In the wake of this and other New Right leaders' victories the neo-liberalism they advocated had a significant impact on the public and private sphere if judged by the rise of rapacious consumerism and the significant growth in the size and reach of the marketing industry.

It was fitting that a politician like Reagan committed to market driven economics should also play such a major role in overseeing the marketization of democratic politics itself (Savigny and Wring, 2009). This process was manifested in the prominence of electoral advertisers ('image makers'), public relations consultants ('spin doctors') and opinion researchers ('pollsters'). Although each of these sets of actors had long played a role in campaigns, the growing influence of these 'electoral professionals' towards the end of the $20^{\text {th }}$ Century had a profound impact on the organization of parties, the state and interest groups. This was demonstrated by the increasing exportation of United States consultancy to newly democratised countries in Latin American and Eastern Europe during this period. Furthermore the centrality of marketing to political discourse was underlined when those who had lost to the New Right began to emulate their 
campaigning approach. The result was the highly image conscious rebranding of the 'New' Democrats.

The term Americanization has surfaced and resurfaced in debates about political communication in Britain involving not just academics but also the candidates and particularly their strategists. The following discussion explores this by focusing on the experiences of Labour before it too adopted the prefix 'New'. Compared to the Conservatives, the party was more democratic and prone to discussing issues- and trying to resolve its differences- in public. Labour was also less reconciled to using communication professionals than their principal rivals and this meant its eventual acceptance of such innovations had broader significance in confirming the nature of British campaigns had been transformed.

\section{Campaigning: practical perspectives}

The growth of mass politics provided major strategic challenges as well as opportunities to those responsible for organising British campaigns. Increasingly politicians and their advisers sought to draw on marketers for advice and insights. Additionally they began to consider and review developments overseas. Writing in 1937 'a prominent advertising expert' explored the impact of propagandistic techniques by reviewing the experiences of not only dictatorships but also American presidential candidates in an article subtitled the 'importance of "human appeal" in printing, the psychology of attention and interest' (Wring, 2005). Clearly invoking ideas popularised by Wallas, Lippman and others the article argued political publicity would work best if it 'avoids detail and concentrates on very broad simple human issues, which mean something at a glance to everybody, including the harassed preoccupied housewife and mother; uses colour, both literally and metaphorically; and uses pictures' (ibid). Significantly this kind of advice informed that year's London local elections, a race that broke significant new ground in the way a Labour campaign operated. 
The London Labour leader Herbert Morrison's victory in the 1937 local elections on an improved share of $51 \%$ of the vote followed a get out the vote effort devised with the help of a team of leading marketing professionals who he had met and cultivated during his previous three years running the capital's authority. Although it cannot be verified there was a perception that a campaign labelled 'the most professional ever fought in Britain' had made the difference to the result. Morrison's re-election caught the attention of Ralph Casey, one of the first academics to study political communication in Britain. The predisposition of Casey, a colleague and collaborator of Harold Lasswell, to focus on presentation was in part borne of his pioneering role in propaganda analysis and journalism education within his native United States. Writing on the 1937 London campaign he noted Labour's use of 'young liberal-minded advertising men and public relations specialists... marked a departure from the usual labour-movement tradition of relying on a staff of journalists for propaganda services' (Casey, 1944). Significantly another US scholar visiting Britain during this period to observe the party at close quarters was also impressed and even suggested it 'perhaps surpasses in effectiveness the most highly perfected American political machines sustained by spoils' (McHenry, 1938: 303).

The nature and aftermath of his re-election gave Herbert Morrison a considerable powerbase at London's seat of government in County Hall and encouraged the kind of self-belief that led him to try and outmanoeuvre his party leader Clement Attlee to become Prime Minister a few years later. This and other actions led historian Kenneth Morgan to draw the parallel between a notorious American politician and Morrison when he described the latter as a 'Tammany right-winger' and 'professional machine man' (Morgan, 1992: 178, and 182). This controversial image of the London leader still persists and yet despite his own robust approach to colleagues he was also a subtle and relatively innovative strategist when it came to handling the media. Morrison's interest in journalism was informed by his own past career working in the newspaper industry and so more than many of his peers he appreciated what made for a good press story. 
He was also keen to help Labour adapt to the radio and television age and in 1951 recruited newly elected MP Tony Benn, a former producer with the BBC North American service, to help advise the party on broadcasting. Benn, like his Conservative counterpart John Profumo, subsequently visited the United States to observe the 1952 presidential election to gain an understanding of how television was reshaping political communication. The visit, and a meeting with the then Democratic candidate Adlai Stevenson, convinced the MP that his party needed to better understand and use broadcasting to present its case to regain power having lost the 1951 British General Election (Wring, 2005).

Tony Benn played a significant role in managing Labour's television operation and by 1959 was fronting some of its free-to-air Party Election Broadcasts. That year's campaign was also noteworthy for the way the Conservatives worked closely with their advertising agency to produce a highly polished strategy. MP Patrick Gordon-Walker, who had been Labour's first ever broadcasting officer, denounced this partnership as evidence of the 'worst sort of Americanisation' in warning against the supposed dangers posed 'by the introduction here of high pressure advertising techniques aimed at the hidden persuasion of the electors' (Rose, 1967: 63). His colleague Alice Bacon, chair of the party's publicity committee, told parliament of her fears that politics would 'become a battle between two Madison Avenue advertising agencies' and blamed the Tories for introducing 'something alien to our British democracy'. But other Labour figures disagreed and looked for inspiration from elsewhere, particularly following a 1959 election that had marked their party's third defeat in a row.

Returning from observing the 1960 US presidential race, Labour activist Bernard Donoughue said his experience as a volunteer on the Kennedy campaign 'did have quite an affect on me. When you came back from America the Labour party really did look like something out of a museum'. His view that his party could learn from the Democrats was shared by leading party theoretician Tony Crosland who saw the potential benefits in emulating the Kennedy strategy and, 
in particular, his 'New Frontier' theme (Wring, 2005). Perhaps the most considered endorsement of this approach came in one of the first lengthy evaluations of Labour's political communications by candidate Christopher Rowland. Rowland pointedly and positively referred to the cultural challenge of 'Americanisation' in justifying a more image conscious approach to party campaigning (Rowland, 1960). Similarly a likeminded report acknowledged British politics was experiencing a period in which the image of the leader had become increasingly important because they were 'the party in camera' (Young Fabian Group, 1962). The same briefing also discussed the arrival of a 'permanent campaign', using a phrase later popularised by American commentator and later Clinton advisor Sidney Blumenthal in his book of the same name (Blumenthal, 1982).

The 1959 election defeat led to sustained debate within the party and wider Labour movement over political strategy. Part of this discussion revolved around a series of articles based on polling research that first appeared in the journal Socialist Commentary and were then subsequently published as a book Must Labour Lose? (Abrams et al., 1960). The periodical, which had close links to and shared contributors with the CIA funded Congress of Cultural Freedom's Encounter magazine, promoted a so-called 'revisionist' cause that urged the party to moderate its policies, particularly on public ownership or what was then more commonly known as 'nationalisation' (Stonor Saunders, 2000). Must Labour Lose? cited polling evidence to endorse and promote this message. Such sentiments earned a rebuke from more radically minded party figures who feared they were part of a campaign for 'reshaping' Labour 'in the image of the American Democratic Party' so as to 'manage capitalism as competently as the Tories' (Crossman, 1960). Similarly leading left-wing intellectual EP Thompson denounced the growing influence of psephology or, as he termed it, 'ephology'. He asserted it was a foreign phenomenon only worthy of publication 'in the American Journal of Communicational Guphology' (Black, 2004: 173). 
Prior to becoming Labour leader Harold Wilson had been sceptical about the need for the party to use the media transform its image. However Wilson would oversee a major transformation of the party's approach to political communications. His rhetoric about a 'New Britain' aped the American Democrats' 'New Frontier' and, in doing so, the new leader became and enjoyed his reputation as a 'Kennedy-type figure' (Pearson and Turner, 1965: 261). Wilson maintained an influential kitchen cabinet throughout his period as Prime Minister and continued to take a keen interest in US innovations. Nixon's triumph in the 1968 presidential race led to private screenings of that campaign's spots in Downing Street with the premier and his advisors taking great interest in this 'fascinating' material. During this period Wilson engaged two North American opinion researchers, Conrad Jamieson and Robert Worcester, to undertake polling for the party. Worcester eventually secured the contract and his MORI agency would continue to work for Labour until well into the mid-1980s (Wring, 2005). But it was following Labour's 1983 election defeat that new party leader Neil Kinnock embarked on the most wide-ranging reform of party structures in half a century.

Marketers, including political consultants visiting from the United States, helped Kinnock transform the organization and centralise authority within his own leadership coterie. The process was encouraged by a similar trend in American politics over the previous generation whereby the balance of power between presidential candidates, their parties and hired election strategists changed in that 'advertising agencies have simply been muscled out of the business by the new corps of political media consultants' (Hill, 1984). Consequently the rise of professional specialists diminished the significance and influence of Labour's existing committee based decision-making structures. The leader and his mainly unelected advisors were therefore able to work on a more fluid, ad hoc basis with a growing cadre of consultants on what were increasingly more capitally intensive campaigns. The new way of doing things was more like the 
Conservatives' approach to strategy in that there was now little accountability to the wider party.

The Labour leadership's greater autonomy led to the hiring of a series of leading US campaign consultants from the mid-1980s onwards. Key Kinnock aides Philip Gould and Patricia Hewitt first met and developed links with the veteran strategist Joe Napolitan at an International Association of Political Consultants conference. The consultant and another American Sally Hunter, an expert filmmaker, were recruited to advise the party. Napolitan's candid advice extended beyond mere presentation to comment on policy when he likened Labour's then unilateral nuclear defence policy to US Democratic candidate Walter Mondale's allegedly vote losing commitment to raising taxes during the 1984 presidential race (Wring, 2005). The American's desire to speak truth to power was again in evidence following the party's 1987 defeat when he suggested, on at least two separate occasions, that Neil Kinnock should resign given his poor public opinion ratings. This was despite him receiving the ultimate 'compliment' from Joe Biden who had plagiarised one of Kinnock's most inspirational speeches in seeking to become the Democratic presidential candidate in 1988.

Although the Biden incident succeeded in derailing the American's own campaign it did not seemingly improve the Labour leader's standing because many commentators continued to argue for his replacement. Kinnock was, however, protected by the structural changes he himself had overseen and a crucial dimension to this was the influential group of his own appointees who helped him to survive and lead the party to a fourth defeat in 1992. Some of this coterie worked closely with other American consultants such as Bob Shrum, Mark Mellman and Ed Lazarus although when asked Labour's campaign manager was evasive about their exact role (Wring, 2005). The secrecy surrounding the party's involvement with such contacts continued. In the preparations for and during the finally victorious 1997 election the involvement of 
pollster Stan Greenberg at Labour's headquarters was kept from the media. This residual nervousness about an American strategic presence was perhaps surprising given Greenberg had been one of several prominent Democrats to address a 1993 conference on 'Clinton Economics'. The event was organised by self-styled Labour 'modernisers' who looked to the recent US election outcome for inspiration. Gould and Hewitt, the pairing who had first met Napolitan nearly a decade before, wrote a piece on 'Lessons from America'. Democrat strategist Paul Begala helpfully summarised the thrust of this analysis when he concluded 'Clinton's genius was to understand that the Democratic Party did not operate on a Left/Right basis and he changed the nature of the dialogue to that of between the old and the new, between elitism and populism' (Wring, 2005).

It was little surprise that the most prominent Labour modernisers Gordon Brown and Tony Blair should embrace so-called 'Clintonization' in order to try and influence party strategy. Shadow Home Secretary Blair cited the communitarian ideas of Amitai Etzioni, a public intellectual associated with the US president, to help formulate a 'new' approach to law and order. And this gave him one of his most memorable soundbites to sum up this revisionism: 'tough on crime, (and) tough on the causes of crime'. This pithy phrase, allegedly developed by Brown, helped promote Blair as the frontrunner when the unexpected 1994 party leadership election was made necessary following the sudden death of incumbent John Smith. On becoming leader the Democrat experience was again invoked to help justify 'New' Labour's further repositioning in pursuit of a supposed 'third way' beyond the 'new right' and 'old left'. And helping guide the pursuit of this philosophy, particularly as it was justified in the successive election victories of 1997, 2001 and 2005, were Clinton consultants Stan Greenberg and latterly Mark Penn.

\section{Conclusion}


This brief survey of what has been routinely referred to as the 'Americanization' of political communication began by pointing out the limitations of this as an organizing concept for describing how campaigning has changed in post-war Britain. However the discussion has also demonstrated how American thinking and practitioners have informed both the study and approach to electioneering in the UK. Particularly important here is recognition that this cross-fertilization of ideas and contacts began before the Reagan-Thatcher ascendancy let alone the Clinton-Blair era. But because of differing political institutions and culture, media systems, levels of campaign finance, geography and a host of other reasons British parties have not simply been able (or have aspired) to borrow strategies and techniques from their Stateside counterparts. American campaign consultancy remains a distinct phenomenon because of the country's unique political economy of elections (Sussman, 2005). British and other countries' electoral races have involved considerably less capitally intensive resources and this remains an obvious barrier to the further cross-fertilization of US originated strategic ideas and practice.

Abrams, M. and Rose, R. with Hinden, R. (1960) Must Labour Lose? London: Penguin.

Altheide, D. and Snow, R. (1979) Media Logic. California: Sage.

Bernays, E. (1923) Crystallizing Public Opinion. New York: Boni and Liveright.

Black, L. (2004) The Political Culture of the Left in Affluent Britain 1951-64, Hampshire: Macmillan Palgrave.

Blumenthal, S. (1982) The Permanent Campaign. New York: Simon \& Schuster. Blumler, J., Kavanagh, D. and Nossiter, T. (1996) 'Modern Communications versus Traditional Politics in Britain: Unstable Marriage of Convenience', in Swanson, D. and Mancini, P. (eds) Politics, Media and Modern Democracy: An International Study of Innovations in Electoral Campaigning and Their Consequences. Westport: Praeger. 
Casey, R. (1944) British Politics: Some Lessons in Campaign Propaganda, Public Opinion Quarterly, Spring, pp.72-83.

Crossman, R. (1959) Labour and the Affluent Society. London: Fabian Society Tract 325.

Downs, A. (1957) An Economic Theory of Democracy. New York: Harper and Row.

Farrell, D. (1996) 'Campaign Strategies and Tactics', in LeDuc, L. et al. (eds) Comparing Democracies: Elections and Voting in Global Perspective, Thousand Oaks, California, 160-183

Habermas, J. (1962) The Structural Transformation of the Public Sphere. Oxford: Polity (republished in 1989).

Higham, C. (1920) Looking Forward: Mass Education Through Publicity. London: AA Knopf.

Hill, D. (1984) Political Campaigns and Madison Avenue: A Wavering Partnership, Journal of Advertising, 13:3, pp.21-26.

Kelley, S. (1956) Professional Public Relations and Political Power. Baltimore: John Hopkins Press.

Kotler, P. and Levy, S.J. (1969) Broadening the Concept of Marketing, Journal of Marketing, 33:1, January, pp.10-15.

Lippman, W. (1922) Public Opinion. London: George Allen \& Unwin.

McHenry, D. (1938) The Labour Party in Transition 1931-38. London: George Routledge \& Sons.

Michels, R. (1915) Political Parties. New York: Free Press.

Morgan, K. (1992) Labour People. Oxford: Oxford University Press. Revised Edition.

Negrine, R. (2008) The Transformation of Political Communication. London:

Palgrave.

Ostrogorski, M. (1902) Democracy and the Organisation of Political Parties. Chicago: Quadrangle.

Pearson, J. and Turner, G. (1965) The Persuasion Industry: British Advertising and Public Relations in Action. London: Eyre \& Spottiswoode. 
Perry, R. (1984) Programming the President. London: Aurum.

Rose, R. (1967) Influencing Voters. London: Faber and Faber.

Rowland, C. (1960) Labour Publicity, Political Quarterly, 31, July.

Savigny, H. and Wring, D. (2009) An ideology of disconnection: For a critical political marketing, Central European Journal of Communication, 2:2, pp.251-266

Stonor Saunders, F. (2000) Who Paid the Piper? The CIA and the Cultural Cold War. London: Granta.

Sussman, G. (2005) Global Electioneering: Campaign Consulting,

Communications and Corporate Financing. Maryland: Rowman and Littlefield.

Swanson, D. and Mancini, P. (1996 eds.) Politics, Media and Modern Democracy: An

International Study of Innovations in Electoral Campaigning and Their Consequences. Westport: Praeger.

Wallas, G. (1908) Human Nature in Politics. London: Constable.

Westen, D. (2007) The Political Brain: The Role of Emotion in Deciding the Fate of the Nation, New York: Public Affairs.

Wring, D. (2005) The Politics of Marketing the Labour Party. Basingstoke:

Palgrave.

Young Fabian Group (1962) The Mechanics of Victory, Young Fabian Pamphlet, February.

Author Note: Dominic Wring is Professor of Political Communication at Loughborough University. He is author of The Politics of Marketing the Labour Party (Palgrave, 2005), a former editor of the Journal of Political Marketing and lead editor of Political Communication in Britain: the Leader's Debates, Campaign and Media in the UK General Election of 2010. 